\title{
Sustainable Revolutions in Agriculture, A Comment on Schwenke and KyndtArticle
}

\author{
Enrique A Martínez* \\ Center for Advanced Studies in Arid Zones, CEAZA, Coquimbo, Chile and Foyer de Charité de Sufferchoix, France
}

Submission: March 21, 2018 Published: July 06, 2018

"Corresponding author: Enrique A Martinez, Center for Advanced Studies in Arid Zones, CEAZA, Coquimbo, Chile and Foyer de Charité de Sufferchoix, France, Email: Enrique.a.martinez@ceaza.cl

\begin{abstract}
A recent opinion points out that the history of agricultural sustainability has followed three revolutions including agro-chemicals, genetically modified organisms and precision and information technologies. Here, I show evidence that these factors have not been source of sustainability and that in particular the so called "green revolution" has provoked a huge ecological and humanitarian debt, and hunger has not stopped. I agree with the authors in that the agricultural revolutions have not finished, but they will be set on more ecological bases, much respectful of soil and biodiversity conservation, such as permaculture. And finally I suggest that technological advancements should address such goals.
\end{abstract}

Keywords: Biodiversity lost; Farmers suicides; Soil erosion

\section{Opinion}

In a recent opinion, on this same journal, the topic of sustainable revolutions in agriculture was addressed by Schwenke and Kyndt [1]. In their opinion three revolutions in agriculture improved yields and thus helped to fight against world hunger. This, in a succession of events starting with the so called "green revolution" with much gains in crop yields, particularly after the seventies. Then a "gene revolution" where genetically modified organisms (GMO's) allowed new improvements by allowing crops to be tolerant to herbicides (for example Round-up ready crops) or to grazing by herbivores (for example Bt-cotton). Finally, technological improvement was added by using sophisticated sensor-based systems to obtain more precise irrigation, and thus making greater economies on farm budgets.

In my opinion the real "green revolution" is just starting. The first so called "green revolution" was rather a "chemical revolution" that allowed strong yield increases by the use in the soils of inorganic chemicals (Nitrates, Phosphates, Potassium) as plant nutrients. In addition to the use of pesticides and herbicides derived from the oil industry, all these modifications also increased yields. Of course, the green side of crops was increased. However, huge environmental and human costs were payed, and the ecological and human debt will last for decades yet. Costs of this debt are related to greenhouse gases (GHG) liberated to the atmosphere. Gases released from diesel use in agricultural machines and also released from the fabrication of the agro-chemicals. Furthermore, we have to add the costs of losing the agrobiodiversity of crops (fewer varieties used by farmers). Also, we have the effects on the biodiversity of plants, insects, those controlling some pests and also pollinators, and other animals of the food networks. Another cost is erosion on soils, those left without vegetal cover due to bad agricultural practices like heavy machines that compact the soils, requiring then deeper plowing, or where tilling eliminates organic matter and all with the excess use of herbicides. Such soil erosion is hard to recover as 35 centimeters of soil is formed after 30 thousand years. Yearly, anthropogenic soil erosion removes 26 Giga tons of soils, 2.6 times the amount of natural erosion so reaching between 0.3 and $0.5 \%$ of soils lost per year [2]. In addition forest, including half of the Amazonian deforestation and burnt, for clearing zones for pasturage to feed cows. Thus, the carbon footprint of agriculture is increasing and the IPPC report on climate change causes points out that the whole set of such agricultural practices contributes to $14.5 \%$ of GHG released to the atmosphere [3], reaching $80 \%$ in some countries, only due to livestock rearing [4].

The real "green revolution" is the improvement of soil management practices for conserving soils, the actual capital of farmers. This real green revolution will increase the number of 
associated crops per hectare, it will have no modification of soil structures and it has been proposed by several authors under the general term of permanent agriculture or permaculture, a new regard based on very old, say millenary traditions, which go well beyond the realm of agriculture [5]. This kind of agriculture is capable of producing more yields (and incomes), without agrochemicals and at the same time protecting soils from erosion and protecting also the landscape from losing its biodiversity, as said in a French study report of INRA-AgroParisTech ${ }^{1}$.

Besides, hunger effectively decreased after the Second World Warbut old colonized African countries, Asia and India kept suffering hunger until our days with a recent increase in the numbers, as shown the Food and Agricultural Organization (FAO) of the United Nations ${ }^{2}$. Also, most modern agricultural improvements remained mostly at the reach of richer big scale farmers. Those small scale farmers from poor countries became highly indebted, even to the point increased suicide rates among farmers in many countries, even in USA [6]. Hunger also is related to politics of poor countries besides huge food waste $\mathrm{w} \mathrm{h} \mathrm{i} \mathrm{c} \mathrm{h}$ has reached rates as high as one third of food lost and wasted from production to consumption chains, as stated also by FAO in $2011^{3}$.

Finally, I completely agree with Schwenke and Kyndt [1] in that: "...we have not seen the last phase of the sustainable agriculture revolution...." However technological improvements should be seen on areas like lighter agricultural machines to provoke less compacted soils, better plant associations to increase soil cover and reduce erosion, better rotation practices, increase of old crop variety uses, less use of agro-chemicals, to improve biodiversity, health on plants, health on humans and thus improving human economy. Also, we should promote the use of compost, earth worms rearing and use of animal manure to fertilize the soils. All such practices will make greener cultivated fields, less greenhouse gas emissions from agriculture, an activity that should assimilate Carbon dioxide instead of being a $\mathrm{CO}_{2}$ emission factor.

\section{References}

1. Schwenke D, Kyndt J (2017) The sustainable revolutions in agriculture. Agricultural Research \& Technology. Open Access J 11(4): 555820.

2. Nahon D (2008) L'épuisement de la terre, l'enjeu du XXIe siècle. Odile Jacob pp. 235.

3. IPCC (2013) Climate Change 2013: The Physical Science Basis Contribution of Working Group I to the Fifth Assessment Report of the Intergovernmental Panel on Climate Change. In: Stocker TF, Qin D, et al. (Eds.), Cambridge University Press, Cambridge, United Kingdom and New York, NY, USA, pp. 1535.

4. Becoña G, Astigarraga L, Picasso VD (2014) Greenhouse gas emissions of beef calf-cow grazing systems in Uruguay. Sustainable Agricultural Research 3: 89-105.

5. Suh J (2014) Towards sustainable agricultural stewardship: Evolution and future directions of the permaculture concept. Environmental Values 23: 75-98.

6. Ringgenberg W, Peek-Asa C, Donham K, Ramirez M (2017) Trends and Characteristics of Occupational Suicide and Homicide in Farmers and Agriculture Workers, 1992-2010: Suicide and Homicide in Farmers and Ag Workers. The Journal of Rural Health 34(3): 246-253.

\section{Your next submission with Juniper Publishers will reach you the below assets}

- Quality Editorial service

- Swift Peer Review

- Reprints availability

- E-prints Service

- Manuscript Podcast for convenient understanding

- Global attainment for your research

- Manuscript accessibility in different formats

( Pdf, E-pub, Full Text, Audio)

- Unceasing customer service

Track the below URL for one-step submission

https://juniperpublishers.com/online-submission.php

${ }^{1}$ https://inra-dam-front-resources-cdn.brainsonic.com/ressources/afile/362783-745d0-resource-rapport-final-bec-hellouin.pdf

${ }^{2}$ http://www.fao.org/3/a-I7695e.pdf

${ }^{3}$ http://www.fao.org/food-loss-and-food-waste/en/ 